\title{
䊦
}

\section{Chimeras: an ethical consideration}

\author{
H.J.G. Zandman \\ School for Ecclesiastical Studies \\ Potchefstroom Campus \\ North-West University \\ POTCHEFSTROOM \\ E-mail: hermzandman@bigpond.com
}

\section{Abstract \\ Chimeras: an ethical consideration}

Scientists have started with experimentation that raises difficult ethical questions. It comprises taking material from the human blueprint (DNA) and inserting this in various test animals. The purpose of such research is noble, namely the alleviation of human suffering. Yet the ethical ramifications of blending the human and animal genome are significant, especially for Christians. The creation of all living entities after their kind and the image-bearing dignity attributed to man both come under severe ethical stress for those who presuppose divine order in God's ecology.

For non-Christians the philosophical dilemma ought not to exist in the ethical sense if applied at the purest level. If the human is merely a kind of animal, along with and ontologically not different from other animals, there is little logical reason to object to chimeric research apart from a concern about what such research and application might do to the order of life pragmatically. However, many non-Christian do object. Man is made in God's image and the concept of human dignity and a universal sense of right and wrong still binds Christians and non-Christians when considering ethics in the field of chimeric research. As the mixing of human stem cells with embryonic animals takes place, certain non-Christian authors protest that human dignity is being diminished and the animal essence is being violated.

\section{Opsomming}

\section{Chimeras: 'n etiese oorweging}

Wetenskaplikes het met navorsing begin wat moeilike etiese vrae teweegbring. Die navorsing behels dat die menslike blou- 
druk (DNS) geïsoleer word en dan in verskeie toetsdiere geplaas word. Die doel van hierdie navorsing is eerbaar, naamlik die verligting van menslike lyding. Nietemin, die etiese gevolge van die samevoeging van 'n menslike en dierlike genoom is gewigtig, veral vir Christene. Die skepping van alle lewende wesens (elkeen volgens sy soort) en die beelddraende waardigheid van die mens kom onder geweldige etiese druk vir diegene wat 'n goddelike orde in God se ekologie vooronderstel.

Vir nie-Christene behoort die filosofiese dilemma eintlik nie 'n etiese kwessie te wees indien dit op die suiwerste vlak toegepas word nie. Indien die mens bloot as 'n soort dier beskou word wat ontologies nie van die ander diere verskil nie, is daar min logiese rede vir besware teen chimeriese navorsing - behalwe vir die kommer oor wat sodanige navorsing en die toepassing daarvan op 'n pragmatiese vlak aan die orde van lewe sal doen. Tog bestaan daar talle nie-Christelike teenstanders. Die mens is na God se beeld geskep en die konsep van menswaardigheid en 'n universele sin vir reg en verkeerd bind steeds Christene en nie-Christene saam in die oorweging van chimeriese navorsing. Terwyl die vermenging van menslike stamselle met embrioniese diere plaasvind, protesteer sommige nieChristelike outeurs dat menslike waardigheid aangetas word en die wese van die dier geskend word.

\section{Introduction}

The incisiveness with which the Lord God set boundaries between various genders of living beings in creation (Gen. 1), and the apparently resolute prohibition implied regarding genetic mixing have both been determinative for Christian ethicists and theologians. The directives are clear about how life should unfold, how to propagate, and how to exercise stewardship over the world as determined by the Creator God.

With the development of science, boundaries of knowledge and resultant application have branched out more widely today than ever before, bringing with it the necessity to articulate anew the terms of appropriateness regarding human stewardship under God. God created man in his image, which is as an ethical being, as someone in need of moral directives to act with moral soundness. Man will always act morally, but the adjudication regarding soundness (or lack thereof), depends on the framework within which this moral action takes place.

With the expanding scientific knowledge, doctors have been transplanting baboon hearts, pig valves and other animal parts into peo- 
ple for decades (Cobbe, 2006:298-302; Krauthammer, 1984:4). Of course, this transplantation of animal organs into people is not chimeric in nature. With the growth in stem cell research, however, this whole-organ transplant has been a precursor to more in-depth experimentation, namely genetic transference between animals and humans, as recent history testifies. The British Academy of Medical Sciences reported in 2007 that scientists have created thousands of examples of transgenic animals carrying human DNA. According to the report, the in vitro introduction of human gene sequences into mouse cells is a technique now practised in virtually every biomedical research institution across the world (Saletan, 2007:1). At present there is no set of firm guidelines to regulate this research (Mohler, 2007:7-8). This is of concern for Christians and non-Christians alike, since the research results may impact on the ecology of the world we live in, and presents serious ramifications in the realm of biology and bioethics.

A chimera is, in this article, understood to be an organism which contains cells or tissue with a different genotype, brought about by mixing stem cells in individuals from different species of animals with humans. Fusion of embryos or insertion of cells from one embryo (or from stem cells) into another organism can be used to create chimeras. For example, laboratory mice have been created with human immune systems for the purpose of understanding various aspects of immune response (Anon., 2008:3).

The work involved in this type of programme will require ethical debate between scientists, biotechnologists, and ethicists. This debate will, of necessity and from a realistically practical viewpoint, involve both Christians and non-Christians. However, the Christian participants will need to enter this debate with a clear understanding of the biblical precepts that have a bearing on the issue of chimera formation, as defined in the previous paragraph. With maturity of understanding, such precepts will shape the ethical direction, and consequently, the practical application - hopefully that drives the Christian contribution to such research.

Ethics is defined in the Britannica Concise Encyclopaedia (Taylor, 2006) as a branch of philosophy concerned with the nature of ultimate value and the standards by which human actions can be judged right or wrong. In short, ethics is the study of morals, from the Greek ethike philosophia, i.e. moral philosophy (Anon., 2006). Ethics is about evaluating actions in the light of presupposed moral principles. Ethics will take moral principles and adjudicate human activity in their light. Over and against the Christian view of God 
stands that of fallen man, speaking in Christ through the Scriptures as the final reference point in predication. For fallen man the final point of reference is himself. It is of the utmost significance for Christian apologists (and ethicists - HJGZ) that this point be carefully noted (Van Til, 1969:41-42). Biblical ethics has God as the final reference point. Such ethics will draw guiding principles for particular issues and situations from the Scriptures and strive to apply these principles as consistently as possible. Believers in Jesus Christ do not wish to be a law unto themselves, unfettered by external divine requirements. They welcome and love the biblical standard of right and wrong - no matter what it may stipulate for any aspect of life (Bahnsen, 1978:2).

In the research examined to date, the delineation between the principial and the pragmatic is blurred in most instances. What follows is an attempt to present a historical overview of what has been stated regarding this controversial issue to date. Also, a careful and judicious indication is presented, as to what the response of the Christian ought to be, when the final declaration on all issues is intended to be according to the biblical precepts related to God's created order.

\section{Blurred distinctions}

Technically, a chimera is an organism comprised of a mixture of cells from two different species (Connor, 2007:1-4). In this article it is limited to the exchange involving animals on the one hand and humans on the other. The aim of research involving chimeras is to achieve the targeted treatment and hopefully, cure of diseases related to the human brain and nervous system. Scientists have already produced humanised mice with the symptoms of Alzheimer's disease.

Scientists at Stanford University propose to put human brain cells in mouse brains in order to replace dying neurons. Initially, scientists at Stanford reportedly rejected the proposal, but have since approved it, allowing the researchers to produce mice with "some aspects of human consciousness or some human cognitive abilities". Though this is not yet chimeric in character (rather transplanting of entities from one living being into another), it is the precursor to DNA transference, mixing animal and human blueprints. This precursor, according to Mohler, raises the frightening prospect of a human brain within an animal species (Mohler, 2007:7-8). 
Scientists have begun blurring the line between human and animal by producing chimeras. In 2003 Chinese scientists at the Shanghai Second Medical University successfully fused human cells with rabbit eggs. The embryos were reportedly the first human-animal chimeras successfully created. They were allowed to develop for several days in a laboratory dish before the scientists destroyed the embryos to harvest their stem cells (Mott, 2005:1). The position paper on embryonic stemm cell research of the Alzheimer's Society in England declares:

Human admixed embryos are a type of SCNT, whereby genetic information from a human is inserted into an animal egg. They were previously termed 'animal human hybrids'. Stem cells line from this source also have the potential to be an excellent laboratory tool in the search to understand how Alzheimer's disease progresses. The method should allow us to increase understanding of the earliest molecular changes in cells, revealing what goes wrong as they begin to develop signs of Alzheimer's disease. (Sharp, 2009.)

Richard Green, of the Jennifer Trust, a charity for sufferers of spinal muscular atrophy in England, states:

We appreciate that this is a sensitive issue, but believe that stem cell research offers real potential benefit for people affected by spinal muscular atrophy. It would be extremely disappointing if scientists were denied the opportunity to undertake this world leading research for the benefit of people with lifethreatening and debilitating conditions progresses. (Henderson, 2007a:3.)

Hope is also expressed that this research will provide answers in the treatment of multiple sclerosis (Hawkins, 2003:1-3). Josephine Quintavalle of the campaigning group Comment on Reproductive Ethics, expresses the contrary view that such research has little justification in science and even less in ethics (Hope, 2007:1-4). Hawkins comments along similar lines as he declares that

the Human Genome Project has indeed opened a Pandora's Box of questions about how genetic data will be used. There is increasing demand for geneticists to pledge to and maintain high ethical standards. However, we must recognize that many of these standards are usually set by secular criteria. (Hawkins, 2003:1-3.)

Added to the voice of these researchers may be the words of caution by Dr Edu Mulder, Senior Researcher at the Department of 
Perinatology and Gynaecology of the University Medical Centre Utrecht, The Netherlands:

In our field we work with sheep and baboons as being close to our work in gynaecology. Animal experiments are, in my view, always limited. I would, in the words of one of my mentors, promote the research concept of researching as far as possible through the use of animals and then seek clearance to work with people (who would be informed and who would have consented voluntarily, of course). For the chimeric research as described in this article I fail to see value. (Mulder, 2008.)

The most extreme implication of this research would be a primatehuman hybrid, or a human-primate hybrid, depending on which species contributed the most cells to the chimera. For example, it would be possible to "humanise" primates by implanting human DNA that make their tissues suitable for transplant into man, helping to overcome the acute shortage of donor organs. An American team has already tested this idea by replacing $20 \%$ of a baboon's bone marrow with human stem cells. The result is that the baboon has various lineage of human blood cells (Highfield, 1996:3). An apparent lack of respect for experimental subjects is an always present danger, as both animals and humans are used to further research without ethical regard for either contributor (Cobbe, 2007:605-606; Krauthammer, 1984:4).

Groups that have been seeking legal permission to do genetic research involving chimeras, include the group led by Stephen Minger of King's College in London, specifically interested in creating embryonic stem cells from patients suffering from diseases with a genetic basis such as Alzheimer's, spinal muscular dystrophy, and Parkinson's. A team from Newcastle University has the desire to study how stem cells develop into different specialised tissues of the body, so that tissue for transplant operations may be developed. Lastly, a team led by Chris Shaw of King's College (London) and lan Wilmut (Edinburgh University) focuses on embryonic stem cell research to help patients suffering from motor neurone disease. The Newcastle team wants to learn more about how adult tissue can be "reprogrammed" into more primitive cells. The embryo would have to be destroyed by the time it was fourteen days old.

As it turns out, the British Government initially regulated embryonic stem cell research so strictly that researchers were dismayed and disappointed. The researchers claimed that the decision makers have been spooked by "frankenbunny" headlines in newspapers that 
created a momentum in public hysteria about the research (Henderson, 2007c:1-2).

A significant breakthrough for chimeric research came when the HFEA presented the following statement to the public on 5 September 2007:

The decision on how the HFEA should approach the licensing of human-animal hybrids and chimera research has presented a particular challenge as this research is so novel in legal, scientific and ethical terms. In order to ensure that the Authority was able to make an appropriate and reasoned decision, we needed to ensure we had a comprehensive and robust evidence base as a foundation for that decision. Once we had established that such research would legally fall within the HFEA's remit to license, we were then able to start to assess whether such research would, in principle, be necessary and desirable in both scientific and ethical terms. Having looked at all the evidence the Authority has decided that there is no fundamental reason to prevent cytoplasmic hybrid research. (HFEA, 2007:1.)

As a result of this development, which was backed by political decision-making (a cross-party attempt to ban hybrid human animal embryos was defeated on a free vote, by 336 to 176), chimeric research became permissible (MPs back hybrid embryonic research: http://news.bbc.co.uk/2/hi/7407589.stm). This was based on the fact that in March 2007, the House of Commons Science and Technology Committee issued a (second) report, again opposing a ban on chimeric research, this time without dissent. In May 2008 the Bill was changed to drop the ban. The HFEA (2007) also announced in its statement that two applications received before the Bill, requesting permission for chimeric research involving animals and humans, would be considered.

\section{Concerns expressed in the field}

The chimera, a fabulous beast made up of the body parts of many animals, is one of the most enduring figures of legend. Modern science is beginning to bring that myth to life - and while such innovation will always prompt the spectre of the monster in the laboratory, it is only by manipulating the mechanisms of life itself that science is helping to conquer disease (Highfield, 1996:1-4).

A new day dawned in the history of potential humankind on 11 November 1998 when a scientist at the Advanced Cell Technology of 
Worcester, Massachusetts, USA, slipped the nucleus of one of his cheek cells into an enucleated cow egg to yield a cluster of embryonic stem cells containing elements of two species (Wade, 2002: 1 ). The era of the human-nonhuman chimera, or cross-species entity, was born.

It should be stated that countries have radically different positions on the acceptability of chimera production. However, like stem cell procedures, such knowledge exhibits the capacity to seep across national borders and attract varied interest according to the proposed application. Australia, for example, permits therapeutic cloning to generate human embryonic stem cells, but has so far legislatively ruled out chimera production (Modell, 2007:2).

From the ongoing debate in scientific circles it becomes evident that in the late twentieth and early 21 st centuries, consensus regarding chimera research was still some way off. Arguments for and against the research continued to proliferate (Connor, 2007:1-4).

'Patients with incurable crippling diseases may be denied the first effective treatments because of government plans to outlaw the creation of "human-animal" embryos', writes the science editor of The Times. 'The proposed ban on fusing human DNA with animal eggs is an affront to thousands of Britons suffering from conditions such as Motor Neuron Disease and Alzheimer's,' leading scientists said [yesterday]. In an attack on ministers who are seeking legislation to prohibit such experiments, the scientists gave warning that it would deny society one of the most powerful tools for medical research. (Henderson, 2007b: 1.)

If there is no worldview-determined reason to differentiate ontologically between different kinds of life forms, then the sympathy of the logically-thinking reader ought to lie with those who seek genetic research involving chimeras. Nevertheless, emotionally strong expressions colour the letters to the editor the very moment a suggested mixing of human and (other) animal genes becomes the topic of conversation. Such letters do not only come from Christians, but from non-Christians as well (Menache, 2008: Letters to the Editor). The Bible does have an explanation for this emotional reaction, namely that even those who deny God, cannot consistently negate the image-bearing which has been imprinted on them. The Canons of Dort put it well in the third and fourth heads of doctrine, article 4: 
There remain, however, in man the glimmerings of natural light, whereby he retains some knowledge of God, of natural things, and of the difference between good and evil, and shows some regard for virtue and for good outward behaviour. (Anon., 1976:103.)

In this statement the confessional wording echoes Romans 1:18-25 in which the inspired apostle Paul declares that man suppresses the truth in unrighteousness. Man knows the truth and cannot deny his Maker, but fights with it and strives to subjugate it, replacing it with his own personal opinion (which becomes his private gospel from then on). Yet, for all this, letters to the editor still refer to human dignity as one of the main concepts for prohibition of chimeric research.

There are some other reasons for the unrest concerning the mixing of human stem cells with embryonic animals, as it essentially results in creating new species. Biotechnology activist Jeremy Rifkin is opposed to crossing species boundaries because he believes animals have the right to exist without being tampered with or crossed with another species (Mott, 2005:2). David Magnus, director of the Stanford Center for Biomedical Ethics at Stanford University, believes the real worry is whether or not chimeras will be put to uses that are problematic, risky, or dangerous. For example, an experiment that would raise concerns, he said, is genetically engineering mice to produce human sperm and eggs, and then doing in vitro fertilisation to produce a child the parents of which are a pair of mice. "Most people would find that problematic", Magnus said, "but those uses are bizarre and not, to the best of my knowledge, anything that anybody is remotely contemplating. Most uses of chimeras are actually much more relevant to practical concerns" (Mott, 2005:2). It is a shame that Magnus does not choose to elaborate as to why he views the genetic mixing he addresses as bizarre. After all, if evolution of life were true, then mixing and transition, the formation of mutations, can be considered normal and part of the course. In the context of both humanism and postmodernism such developments and manipulations are neither good nor bad, they just are.

Cynthia Cohen is a member of Canadian Stem Cell Oversight Committee, which oversees research protocols to ensure they are in accordance with the new guidelines. She also believes a ban should be put into place. Creating chimeras, she said, i.e. mixing human and animal gametes (sperms and eggs) or transferring reproductive cells, diminishes human dignity. "It would deny that there is something distinctive and valuable about human beings that ought to be honoured and protected", said Cohen, who is also the senior re- 
search fellow at Georgetown University's Kennedy Institute of Ethics in Washington, D.C. She noted, however, the wording on such a ban needs to be developed carefully. It shouldn't outlaw ethical and legitimate experiments such as transferring a limited number of adult human stem cells into animal embryos in order to learn how they proliferate and grow during the prenatal period (Mott, 2005:3).

Well intended as these words sound, they beg the question as to what defines the ethical and legitimate. Her rider (an additional remark following a statement) of using only a limited number of adult human stem cells into animal embryos, is an invitation to lengthy conferences on pragmatism in order to decide what may be considered the limit, and why this subjectively and pragmatically decided limit should be adhered to by scientists all over the world. The ultimate adjudicator in a non-scriptural context will be man's subjectively designed yardstick, and each scientist will use the yardstick set for him by legal restrictions - depending on the legal regime that writes the dictates. Irving Weissman, director of Stanford University's Institute of Cancer/Stem Cell Biology and Medicine in California, is against a ban. Mott (2005:3) reports him as stating:

Anybody who puts his own moral guidance in the way of this biomedical science, where he wants to impose his will - not just be part of an argument - if that leads to a ban or moratorium ... he is stopping research that would save human lives.

Philosophically, without the Scriptural doctrines regarding creation and life as final authority, no objective protest can be made to Weissman's desire. If he wishes to save human lives through chimeric research tools, then he has to be left to do this without being hamstrung by other people's emotional exclamations and personal opinions. It is interesting, however, to observe how Weissman's voice on the issue has become bolder over time.

Three years earlier, Weissman expressed extreme caution when tiptoeing into, what he apparently regarded as a potential scientific minefield. He stated at the time that creating mice with human cells could be "an enormously important experiment", but if done carelessly, could lead to outcomes that are "too horrible to contemplate". He gave as an extreme example the possibility that a mouse, making human sperm, might accidentally be allowed to mate with a mouse that had made its eggs from human cells (Wade, 1998:148).

In the same meeting where Weissman made this view known, another scientist, Fred Gage of Salk Institute, reduced ethics of the 
genetic research with chimeras to the timing of the termination of the life created. He reportedly informed the meeting that, in using mice simply to test the pluripotentiality of human embryonic stem cells, it would not be necessary to let the mice grow to term, and the earlier the mice were killed the less pressing would be the ethical issue. Richard Doerflinger of the National Conference of Catholic Bishops, who has long opposed research with human embryonic stem cells, said (in the same meeting) that his primary objection remained with the first step - that of killing a human embryo to obtain embryonic stem cells. His initial reaction to the proposed experiment was that as a test for pluripotentiality, it might not be objectionable. "If you end up with one human cell per organ of a mouse, I don't think it raises a new problem," he said. "The amounts of human material in an animal would have to be pretty substantial to start talking about a human hybrid, and I don't think this raises that spectre." (Wade, 1998:148.)

It is interesting to note that a Roman Catholic bishop apparently fails to recognise that ethical issues should be discussed on the basis of principle. In verbalising his (quantitatively coloured) view as quoted, he makes the ideological shift from ethics to pragmatism.

\section{Bible guided thoughts on the matter}

Hollander writes that it takes the most profoundly imaginative of human faculties to scrutinise the very limits of those faculties themselves. With respect to our constructions of quasi-personhood for animals we must always know they are our constructions (Hollander, 1995). Yet, when such constructions are firmly embedded in our literary diet, are uncritically given to children to read, are even promoted as wholesome and good because of the moral lessons being taught (Christian Book Distributors, 2006: Kids' store; Rayner, $2005)$, then the distinction between man and the rest of creation inevitably becomes warped in the mind's eye. As Tal Brooke (1997: 178-180) points out, this is exactly man's natural desire ever since the fall into sin. The way of man's in-principle acceptance of chimeric genetic research has been paved over many centuries of literary writings, and lately, other media presentations through which the delineations between man and animals has been blurred (Zandman, 2006:23-24).

The principle of human dignity is recognised by religious faiths far and wide. The Vatican's "Instruction on respect for human life", states "human life must be absolutely respected and protected from the moment of conception" (Congregation for the Doctrine of the 
Faith, 1987:701). The statement representing the Vatican viewpoint is highly complicated by this line of research, because the distinction between human and non-human in the early chimera is blurred (Modell, 2007:2).

There are many pressure groups and religious organisations who have voiced their opposition on the grounds that it is unethical or immoral to mix germ cells from humans and animals to create potentially viable embryos. They believe that it undermines respect for human life, and some believe it is also demeaning to animals (Connor, 2007:1-4). In the biblical view, species integrity is necessarily defined by God the Creator of the species, rather than by arbitrary or evolutionary forces. The fusion of animal-human genomes runs counter to the sacredness of human life and man created in the image of God. The creation of animal-human chimeras as a means of deriving human tissue and organs highlights the deeper issues facing our generation: the new biological genomic revolution and the resultant power that may permit scientists to redesign various species and biological life. We must not allow such an ability to outstrip the ethical analysis that must accompany it (Jones, 2003:2).

Some sacred barrier between species had been broken, some principle of separateness between man and animal violated. "Indeed, it is a blow to man's idea of himself to think that a piece of plastic or animal tissue may occupy the seat of the emotions and perform perfectly well." (Krauthammer, 1984:87-88.)

The sacredness of man as per God's creation when comparing his status with that of animals, is founded in the unique declaration that He created man in his image (Gen. 1:27). Much has been written about what this means, that God created man in his image. John Calvin, after considering various suggestions made by others, arrives at the following conclusion: Since the image of God had been destroyed in us by the fall, we may judge from its restoration what it originally had been. Paul says that we are transformed into the image of God by the gospel. And, according to him, spiritual regeneration is nothing else than the restoration of the same image (Col. 3:10; Eph. 4:23). That He made this image to consist of righteousness and true holiness, is by the figure synecdoche, for though this is the chief part, it is not the whole of God's image. Therefore, the perfection of our whole nature is designated by this word, as it appeared when Adam was endued with a right judgement, had affections in harmony with reason, had all his senses sound and well-regulated, and truly excelled in everything good. Thus the chief seat of the Divine image was in his mind and heart, where it was 
eminent. Yet there was no part of him in which some scintillations of it did not shine forth. For there was an attempering in the several parts of the soul, which corresponded with their various offices. In the mind perfect intelligence flourished and reigned, uprightness attended as its companion, and all the senses were prepared and moulded for due obedience to reason; and in the body there was a suitable correspondence with this internal order (Calvin, 2005:4748).

From Calvin's description, the conclusion may be drawn that man was uniquely equipped to shine forth the attributes of God in this world. He was given the derivative qualities to enable principled approaches and ethically sound application to the stewardship mandate (as stated in Gen. 1:28). Man was set apart in heart and mind to serve God with understanding, and states Calvin, in the body there is a suitable correspondence with the internal order. Man's physical faculties correspond with the non-physical to exercise unique stewardship.

This view is supported by Williams (2005:1) who writes:

What does 'human' mean? For many people, being 'human' means nothing more than 'looking like other people' and being 'ape' means 'looking like apes'. Superficially, we don't look all that different - humans just have less body hair and a more upright stance (actually there is a great deal of difference but I refer here to secular thinking). But God tells us that 'human' means being made like God Himself and being part of God's eternal family (Genesis 1:26-28, Psalm 8 and Hebrews 2:6-11). No animals are given that status.

It may probably be inferred from this that chimeric mixing in the genetic blueprint of humans would lead to deterioration of the balance in internal order, thus causing impairment of man's ability - already hampered by the fall into sin - to exercise good stewardship as God's vicegerent.

Several authors claim that even fundamental statements from Scripture, such as the text of Leviticus 19:19 ("Thou shalt not let thy cattle gender with a diverse kind: thou shalt not sow thy field with mingled seed", KJV), are unclear where chimeric research is involved, which does not involve the sexual transfer of genetic material (Cobbe, 2007:609; Modell, 2007:2).

However, it must be noted that Leviticus 19:19 is not a moral issue in terms of what animals do. For animals the point is that out of the 
mixing of two kinds an undefined creature will possibly emerge. Animals will not make a conscious, moral decision to mix with another kind. Therefore, it appears quite justifiable to draw on the text of Leviticus, because the moral load is on the engineer, the person who causes the engendering. In the ethical context this verse dictates a clear prohibition regarding man's potential inclination to transgress the boundaries delineated between kinds, as per God's initial creation. (Spiritually, for the nation of Israel, the significance of being set apart by and for God is of course also impressed here. This aspect, however, falls outside the purview of this article.) If the ethical load-bearing of this statement in Leviticus were on the animals themselves, then the prohibition stated here would leave one to wonder about the necessity of such a declaration, because animals are by nature very much averse to mixing with other kinds. What is more, mostly they are not even able to copulate, because of the significant divergence in anatomy between differing kinds (Gnomon, 2007). Yet, when people induce animals, particularly mammals, to particular transgender behaviour, the animals can and, in many cases, will do that which they are driven to do (Solimeo, 2004:1).

Matthew Henry, in addressing Leviticus 19:19, states: "God in the beginning made cattle after their kind (Genesis 1:25) and we must acquiesce in the natural order God has established, believing it is best and sufficient, and not to covet monsters." (Henry, 1992:407.) This is echoed by John Wesley (http://www.christnotes.org/ commentary) who writes:

This (i.e. the command: You shall not let your livestock breed with another kind - HJGZ) was prohibited, partly to restrain the curiosity and boldness of men, who might attempt to amend or change the works of God. (Italics - HJGZ.)

The implication is that the arrogance of man is not to try and improve on what God saw as good, because fallen man can not hope to improve on the good work God has done. Knowing better than God is an attitude leading right back to the Garden of Eden and man's downfall at the dawn of history. Historically, it has only been when man has striven to think God's thoughts after Him (i.e. think ethically as closely as possible according to his Creator's purpose for stewardship), and to exercise vicegerency over the creation entrusted to him, that creation has been blessed. Then its groaning (Rom. 8:22) has been somewhat alleviated where the hand of God, through sanctified management of his people, has been at work. 
Animals were created after their own kind, in their nature, in their shape, in their temperaments, in their ecological functions.

The assertion of Jones that species integrity is defined by God, rather than by arbitrary or evolutionary forces, is crucial to our understanding of this issue. Any effort to violate species integrity no matter how noble with respect to medical treatments - must be seen as suspect in this light (Jones, 2003:2). This (i.e. the refusal to entertain genetic mixing of species) does tend to create a conflict situation between those who have an urgent zeal to alleviate human suffering and those who wish to safeguard the genetic purity of God's handiwork. God has given man stewardship in the context of restoration. In fact, the whole of creation was subjected to futility, is in bondage of corruption, groans and labours with birth pangs (Rom. 8:20-22), and the Christian is encouraged to seek a return to wholeness by pursuing goodness (cf. $1 \mathrm{Tim}$. 6:11). It is difficult to reconcile these two facets of stewardship, both of which are good in and of themselves. Nevertheless, if the biblical arguments proffered by Henry and Wesley are regarded as true by believers of the Bible, and if the viewpoint of Mulder, quoted earlier, appears to give practical support, the conclusion may be justified that inter-species DNA mixing is questionable. Purdom concludes, while responding to questions of a reader, that mutations (which chimeras to a smaller or larger extent are when the DNA of two species is exchanged) are usually harmful - or neutral at best (Purdom, 2008:1). The language coming from laboratories is also couched in careful terms when asked to indicate measures of success in research (Carter, 2007:1; Anderson, 2007:1).

The aforesaid appears to make the case against chimeric research on three mutually supportive points for the Christian argument: Scripturally the line between man and subordinate species is crossed with such research (as defined and delimited in this article); certain scientists hold that research answers must be found for the species in the species so targeted; and to date no medical benefits have been forthcoming from this particular type of research. If Purdom is correct, nor is such benefit likely.

In terms of the possible conflict between those who wish to seek healing for people on the one hand and those who wish to maintain creation boundaries between species in terms of DNA switching, it appears that the weight of argument supports the latter group. It is good to seek healing for ailments, but the threefold assessment detailed above tends to conclude that chimeric research is not the way of advancement. 


\section{Considerations for Christians}

What is the position that Christians should take regarding this issue? Mohler (2007:7-8) claims that there are no clear guidelines in place for believers of the Bible.

What continues to be crucial is that those who hold the biblical perspective will be able to articulate an intelligently founded position while making a stand in terms of this direction of genetic research. It is in that regard a matter of concern that church leaders are seduced into abandoning principled approaches in order to make room for approaches on ethical issues that are defined by words like more or less.

It is important to ascertain ethically whether something should or should not be done at all, as per biblical teachings. If the conclusion reached is that something may justifiably be done, only then the stewardship question of loading and allocation of responsibilities for implementation becomes relevant, i.e. after the ethics question has been addressed. Ethics needs to precede and govern actions for the Christian.

The following cautionary thoughts may assist Christians in voicing a biblical approach to the question of chimeric research.

The ecology of creation has been carefully designed and is delicately balanced. As chimeras are introduced into the system, this may well create problems for a sound equilibrium. Calvin (2005:67) writes in the context of Genesis 2:15 how man should be ecologically responsible.

Let him who possesses a field, so partake of its yearly fruits, that he may not suffer the ground to be injured by his negligence; but let him endeavour to hand it down to posterity as he received it, or even better cultivated. Moreover, that this economy, and this diligence, with respect to those good things which God has given us to enjoy, may flourish among us; let every one regard himself as the steward of God in all things which he possesses.

The argument that chimeras are very necessary to experiment for the benefit of human beings and their health is unproven (Check, 2005:1058-1059; Cibelli, 2007:990-992; Cobbe, 2006:298-302; Hope, 2007:1-4; Knight, 2004:817) and invalid, as stated by some scientists. The great Designer has created mammals and (as research indicates) even other animals (Mulder, 2008), many of 
which are (in the biological sense) close enough to humans to enable research tocombat disease (Wade, 2002:1). Reportedly, the chimpanzee and human genomes are very similar and encode very similar proteins. The DNA sequence that can be directly compared between the two genomes is almost $99 \%$ identical. When DNA insertions and deletions are taken into account, humans and chimps still share $96 \%$ of their sequence, researchers found (Anon., 2005: 1). Mixing kinds, obscuring the boundaries between humans and other kinds, is deemed for that reason unnecessary, ethically questionable even (Calvin, 2005:67).

Humans and animals do have something in common and that is emotional awareness. God created life forms in relational bonds that have emotional loading. It may well be judged serious mismanagement on the part of man, cruelty even to other life forms, to dissociate such a life from the kind in which God placed it. Because of distortions in make-up, such a being may well be hampered in relating, and will therefore be isolated and reduced to loneliness and rejection.

\section{Conclusion}

God has designed the world in an orderly manner and He placed life forms on the earth after their kind. In the context of chimeric research, man is moving across genetic boundaries. The Scriptures make a consistent differentiation between man on the one hand and animals on the other (cf. Lev. 20:16; Ps. 36:6). Particularly difficult becomes the question of ethics regarding chimeric research when remembering the words of God in Genesis 9:3. There, man is given permission to consume animal meat. If one were to imagine that human and animal genomes were mixed (irrespective of the mix loading), how could a person still eat an animal without essentially being cannibalistic at the same time? Also, in various research approaches the chimera is set to be killed after a couple of weeks of research. This gives rise to the ethical question regarding the sacredness of human life, such as it also may be found - to whatever extent - in a chimeric hybrid.

Furthermore, a number of scientists deem the biological similarities between man and many types of animals to provide adequate encouragement for progression in research analysis.

Christians are well advised to beware of confusing principled and practical reasoning when addressing the phenomenon of chimeric research. Rather, they ought to arrive at an ethical position based on 
biblical principles first. Only when clarity has been found regarding scriptural approbation, practical stewardship steps may be considered in the situation of chimeric research.

\section{List of references}

ANDERSON, A. 2007. Chimera controversy. http://scienceline.org/2007/08/31/ bio_anderson_chimera/ Date of access: 23 Oct. 2008.

ANON. 1976. The canons of Dort. (In The Psalter Hymnal: doctrinal standards and liturgy of the Christian Reformed Church. Grand Rapids: Board of Publications of the Christian Reformed Church.)

ANON. 2005. Decoded chimpanzee genome shows striking similarity with human's. http://www.highbeam.com/doc/135677166.html Date of access: 5 Jan. 2009.

ANON. 2006. Online Etymology Dictionary - ethics. http://www.etymonline. com/index.php?term=ethics Date of access: 25 Aug. 2008.

ANON. 2008. Genomics. http://www.ontariogenomics.ca/main/glossary.asp? alpha=c\&l= Date of access: 18 Oct. 2008.

BAHNSEN, G. 1978. Biblical ethics: God's word, our yardstick. Vol. 1:2. Tyler: Institute for Christian Economics.

BROOKE, T. 1997. Virtual gods. Eugene: Harvest House.

CALVIN, J. 2005. Calvin's Bible commentaries: commentary on Genesis. Rio: Ages Digital Library. (Christian Library Series.)

CARTER, J. 2007. Of mice and men (and other chimeras). http://www. evangelicaloutpost.com/archives/2007/09/of-mice-and-men. html Date of access: 23 Oct. 2008.

CHECK, E. 2005. Where now for stem cell cloners? Nature, 438:1058-1059.

CHRISTIAN BOOK DISTRIBUTORS. 2006. Catalogue shopping. http://www. christianbook.com/ Date of access: 10 Jan. 2009.

CIBELLI, J. 2007. A decade of cloning mystique. Science, 316:990-992.

COBBE, N. 2006. Why the apparent haste to clone humans? Journal of medical ethics, 32:298-302.

COBBE, N. 2007. Cross-species chimeras: exploring a possible Christian perspective. Zygon journal of religion and science, 42:605-606, 609.

CONNOR, S. 2007. Should we allow the creation of embryos which are animalhuman hybrids? The big question. The Independent, (London): 10, Jan.

GNOMON. 2007. Animal sex. http://www.bbc.co.uk/dna/h2g2/A22547838 Date of access: 6 Dec. 2008.

HAWKINS, G.A. 2003. The genetics of mice and me: can and should we intervene? http://www.cbhd.org/resources/genetics/hawkins_2003-08-15. htm Date of access: 4 Dec. 2008.

HENDERSON, M. 2007a. Cloning can beat disease. http://tls.timesonline.co.uk larticle/0,,8122-2532419_2,00.html Date of access: 19 Dec. 2008.

HENDERSON, M. 2007b. Medicine faces ban on rabbit-human embryos. http://www.timesonline.co.uk/article/0,,8122-2532502_2,00.html Date of access: 19 Dec. 2008.

HENDERSON, M. 2007c. Ministers have been spooked by "frankenbunny" headlines. http://tls.timesonline.co.uk/article/0,,8122-2532419_2,00.html Date of access: 19 Dec. 2008. 
HENRY, M. 1992. Commentary on the whole Bible. Vol. 1: Genesis to Deuteronomy. Peabody: Hendricksen.

HFEA see HUMAN FERTILITY \& EMBRYOLOGY AUTHORITY

HIGHFIELD, R. 1996. Man, beast: perilous mix? Chicago Sun-Times: 3, 18 Feb.

HOLLANDER, J. 1995. I named them as they passed. Social research. http:// findarticles.com/p/articles/mi_m2267/is_n3_v62/ai_17909872/ Date of access: 8 Dec. 2008.

HOPE, J. 2007. Human-animal embryos move nearer to reality: about-turn by ministers opens door to "chimeras" for medical research. Daily Mail: 1-4, 18 May.

http://news.bbc.co.uk/2/hi/7407589.stm Date of access: 26 Mar. 2012.

HUMAN FERTILITY \& EMBRYOLOGY AUTHORITY. 2007. Statement on its decision regarding hybrid embryos in London, England on 5 September.

JONES, N.L. 2003. Could animal-human chimeras be on the way? http://www.cbhd.org/resources/genetics/jones_2003-01-09.htm Date of access: 4 Dec. 2008.

KNIGHT, J. 2004. Biologists fear cloning hype will undermine stem-cell research. Nature, 430:817.

KRAUTHAMMER, C. 1984. The using of baby Fae. http://www.time.com/time/ magazine/article/0,9171,923 Date of access: 21 Dec. 2008.

MENACHE, A. 2008. The rights and wrongs of the embryology bill: you don't have to be a Roman Catholic to find elements of the new bill troubling. The Times (London.): Letters to the Editor, 25 Mar.

MODELL, S.M. 2007. Approaching religious guidelines for chimera policymaking. http://www.blackwell-synergy.com/doi/pdf/10.1111/j.14679744.2007.00855.x Date of access: 6 Dec. 2008.

MOHLER, A. 2007. The chimeras are coming. Connexions, (24):7-8.

MOTT, M. 2005. Animal-human hybrid sparks controversy. http://news. nationalgeographic.com/news/2005/01/0125_050125_chimeras.html Date of access: 24 Oct. 2008.

MULDER, E.J.H. 2008. Personal communication on: "The health-promoting value of chimeric research". De Bilt, Netherlands. (Interview available.)

PURDOM, G. 2008. Feedback: are there beneficial mutations? http://www.answersingenesis.org/articles/2008/04/25/feedback-beneficialmutations Date of access: 23 Oct. 2008.

RAYNER, M. 2005. Introducing Christian virtues using Aesop's fables. http://www.learninghouse.ca/productscat.php?process=details \&pubID=\&c atID=6\&subcatID=44\&titleID=130 Date of access: 23 Jan. 2009.

SALETAN, W. 2007. Making manimals. Washington post: p. 1, 24 Jun.

SHARP, S. 2009. Stem cell research. http://alzheimers.org.uk/site/scripts/ documents_info.php?documentID=1039 Date of access: 24 Mar. 2012.

SOLIMEO, L.S. 2004. The animal homosexuality myth. http://www.narth.com/ docs/animalmyth.html Date of access: 6 Dec. 2008.

TAYLOR, I. 2006. Ethics. http://www.answers.com/topic/ethics-legal-term? cat=biz-fin Date of access: 20 Aug. 2008.

VAN TIL, C. 1969. A Christian theory of knowledge. Phillipsburg: Presbyterian \& Reformed Publishing.

WADE, N. 1998. Human cells revert to embryo state. New York Times: 148, 12 Nov. 
WADE, N. 2002. Comparing mouse genes to man's and finding a world of similarity. www.nytimes.com/2002/12/05/us/comparing-mouse-genes-toman-s-and-finding-a-world-of-similarity.html Date of access: 6 Dec. 2008.

WESLEY, J. Leviticus 19: Wesley's explanatory notes. http://www.christnotes. org/commentary

WILLIAMS, A. 2005. Of mice and men - and the monsters in-between. http://www.answersingenesis.org/docs2005/0425chimera.asp Date of access: 23 Oct. 2008.

ZANDMAN, H.J.G. 2006. Creation merger, ethical mixing. (Private research; Unpublished.)

Key concepts:

boundaries

chimeric research

conflict

ethics, Christian

health

Kernbegrippe:

chimeriese navorsing

etiek, Christelik

gesondheid

grense

konflik 